\title{
Addressing Sustainable Rural Development with Shared Value: A Peruvian Model from the Cacao Industry
}

\author{
Armando Borda ${ }^{1, *}$, Oswaldo Morales ${ }^{1}{ }^{(\mathbb{D}}$, Hildy Teegen ${ }^{2}$, Gareth H. Rees ${ }^{3}(\mathbb{C}$ \\ and Maria Alejandra Gonzalez-Perez ${ }^{4}$ (D) \\ 1 Graduate School of Business, Universidad ESAN, Lima 15023, Peru; omorales@esan.edu.pe \\ 2 Darla Moore School of Business, University of South Carolina, Columbia, SC 29208, USA; \\ Teegen@moore.sc.edu \\ 3 Faculty of Economics and Management, Universidad ESAN, Lima 15023, Peru; grees@esan.edu.pe \\ 4 Department of Management, Universidad EAFIT, Medellín 050022, Colombia; mgonza40@eafit.edu.co \\ * Correspondence: aborda@esan.edu.pe; Tel.: +51-1-317-7200
}

Citation: Borda, A.; Morales, O.;

Teegen, H.; Rees, G.H.;

Gonzalez-Perez, M.A. Addressing Sustainable Rural Development with Shared Value: A Peruvian Model from the Cacao Industry. Sustainability 2021, 13, 8028. https:// doi.org/10.3390/su13148028

Academic Editor: Riccardo Testa

Received: 4 June 2021

Accepted: 13 July 2021

Published: 19 July 2021

Publisher's Note: MDPI stays neutral with regard to jurisdictional claims in published maps and institutional affiliations.

Copyright: (c) 2021 by the authors. Licensee MDPI, Basel, Switzerland. This article is an open access article distributed under the terms and conditions of the Creative Commons Attribution (CC BY) license (https:// creativecommons.org/licenses/by/ $4.0 /)$.

\begin{abstract}
Here we present a model aimed at contributing to the literature around sustainable supply chains by examining a novel redesign initiative of the chocolate supply chain within the Peruvian cacao (cocoa) industry. Using the Creating Shared Value (CSV) framework, we apply the case study method in examining the Peruvian Cacao Alliance's experience in redesigning both the stages and relationships within its supply of cacao to the world. Data were collected from both primary and secondary sources and analyzed after coding from categories defined in the literature on CSV. The case demonstrates the opportunity to successfully participate in the supply chains of globally recognized, consumer-facing chocolate brands while simultaneously obtaining social, economic and environmental benefits for the rural communities that supply cacao. While addressing both social and business gains remains fairly important for supply chain members, there are several implementation challenges that need to be considered to achieve the goals of CSV strategies in a sustained way. By analyzing the experience of this particular cacao value chain, we are able to offer practical insight on how to more effectively implement the creating shared value approach, thereby illuminating that it is possible for value generated through such supply chains to be more equitably shared. As such, we provide a valuable initial step in better understanding how the CSV concept applies in practice by identifying its boundary conditions for achieving improved cacao supply chain practices and relationships.
\end{abstract}

Keywords: supply chain redesign for sustainability; cacao/cocoa grower participation; shared value; rural development; sustainable supply chains

\section{Introduction}

Since the beginning of the 21st century, both the consumption of chocolate and the industry's market value have grown dramatically. By the end of 2019, the annual global chocolate industry was worth USD 102 billion [1]. It has been forecasted to grow at a cumulative rate of 5\% between 2019 and 2023, with the retail market value estimated to more than double between 2004 and 2023 [2,3], with resulting cacao cultivation in some Latin American counties substantially increasing [4].

Cacao (Theobroma cacao) is the principal ingredient of chocolate, with the domestication of the plant occurring near the Amazon river about 5300 years ago [5]. Cacao is an important economic industry, as it represents the major source of income for millions of small farmers in different continents [6]. Africa is the largest producer by continent, while Latin America's production accounts for about 1/6th of the world's production [7].

However, there are major concerns that have the capacity to threaten the cacao industry's trajectory of growth. One of the most important is associated with sustainable farming and supply chain practices. The relatively fragmented nature of the cacao industry's global 
supply chains, the lack of relevant and transparent information on upstream activities, the structural oversupply and the corresponding pressures to minimize costs are factors paving the way for opportunistic behavior by local intermediaries to the detriment of smallholding farmers [8]. This opportunistic behavior can be revealed in both the prices paid to farmers and on the reliability of the scales used to weigh farmer's production [9], each substantially affecting farmers' incomes and thus livelihoods. For instance, analyzing the chocolate supply chain, the Fair Trade Foundation found that cacao farmers only received around $3.5 \%$ of the final value of a chocolate bar [10]. This is significantly less than the $16 \%$ that they had received in the 1980s. Moreover, cacao producers face short-term volatility in market conditions such as the volumes demanded, preference for specific varietals, requirements of certifications, as well as price instability, which affects their incomes by as much as $30-40 \%$ in a given year [11].

Small cacao farmers disproportionately bear these supply risks while constantly struggling to address basic human subsistence needs through their endeavors. As a response, they may resort to using questionable environmental and/or social practices to increase the production of their plantations, which poses downstream reputational risks for global chocolate brands. With respect to the environment, the most common concerns involve rainforest deforestation and land degradation caused by using slash and burn practices. In terms of social impacts, child labor has been a major issue for the industry for a considerable time. For instance, in 2011, Change.org, a group of consumer rights activists identified that the Hershey chocolate company had been purchasing cacao from farms that practice child labor and began a campaign urging chocolate consumers not to buy Hershey's products until the company had demonstrated its adherence to International Labor Organization guidelines [12].

While global brands have responded to these problems by buying certified-only cacao or establishing their own sustainability programs (such as the "Forever Chocolate" program of Barry Callebaut AG or the "Sustainable in a Generation" plan of Mars Incorporated), the economic and social conditions of small farmers have not notably improved, with many of the problems in the supply chain and their associated risks remaining unchanged [11]. In fact, according to Sylla [13], there are major controversies around the three major certification agencies, Fair Trade, the Rainforest Alliance and UTZ. For instance, only a small fraction of the volume that is produced under the Fair Trade label will obtain minimum volume guarantees and the premium prices expected [14].

Moreover, cacao farmers as well as rural people in cacao growing areas face structural issues, such as the lack of access to finance, skills training and business support that affect livelihood development and productivity improvement $[15,16]$.

Considering the industry's need to increase the living standards of current farmers, to incorporate new farmers into the supply chain to meet growing demand and to diversify varieties of cacao to support the strong growth of the premium category [2], the industry is looking for alternative mechanisms to sustainably obtain new varieties of cacao. Some of these involve working more closely with producers enacting a co-production approach that can improve biodiversity conservation and relationships with small growers [17]. Resulting changes in how supply chains are structured and how relationships are established and maintained have important implications for both the sustainability and profitability of participants. Nevertheless, there is little guidance for firms on how to make their sustainable initiatives profitable, presenting a "frustrating paradox" [18].

In this work, we use the creating shared value (CSV) framework proposed by Porter and Kramer $[19,20]$ to organize our discussion. The CSV framework is ideal to analyze the situation described given its capacity to simultaneously address economic and societal demands by aligning the interests of different parties. First, there is a need for the Peruvian government to fight against narcotics-trafficking in rural areas. Further, there are environmental challenges due to land erosion and deforestation that call for action. Second, farmers need to significantly improve the revenues associated with their crops to both improve their quality of living and substitute illegal crops plantation. Finally, 
large manufacturing companies require securing sustainable and reliable sources of new varieties of cacao to support the strong demand in high-profile confectionery. All these conditions provide a sweet spot to address not only economic concerns but also societal ones. Therefore, in this article, we use the CSV framework to organize a discussion around a novel initiative of redesign to provide a sustainable supply of traceable, fine flavor cacao to enhance competitiveness in the chocolate supply chain while progressing the economic and social conditions of the community [20].

We aim to contribute to the CSV literature by addressing several of its shortcomings that have been highlighted before. Previous research suggests that CSV ignores the costs that are incurred to produce benefits [21] and that it assumes there are no tensions in achieving the "sweet spot" - the place where social and economic benefits meet-and that it largely neglects a systemic perspective while overemphasizing the capacity of a firm to address these benefits simultaneously [22]. Further, there is little research on how organizations are approaching CSV initiatives in practice, and firms seek grounded guidance on how it should be implemented [23]. Lastly, previous research has been criticized for the lack of a multi-stakeholder case approach to provide examples of how firms may simultaneously pursue economic, social and environmental outcomes [21].

We organize the article as follows. First, we describe the "sweet spot", which we define as the opportunity for firms to simultaneously address social and economic benefits followed by a brief summary of the CSV literature. We then outline our data collection process and methods used to develop the focal case and discuss our findings by referring explicitly to the original CSV framework in terms of some of its suggested shortcomings. Finally, we close with some theoretical and managerial implications, limitations and avenues for future research stemming from the present analysis.

\section{Materials and Methods}

\subsection{Context of the Study: The Sweet Spot-Fine-Flavor Cacao in Peru}

Located in west-central South America, Peru is among the ten most biodiverse countries on the planet [24]. This diversity is reflected in the number of the country's cacao species and the growing recognition of the quality of Peruvian cacao beans for the distinct flavors, scents and fat content that these varieties provide [25]. Plant biodiversity has also led Peru to become one of the most important producers of coca (erythroxlyum), the leaves of which are used to produce the illegal narcotic cocaine [26]. Cacao and coca are both grown in similar environments in Peru. As most Peruvian-grown coca leaves are associated with illegal drug trafficking [27], the country's unique cacao biodiversity provides an opportunity to: (i) substitute smallholder farm production away from illegal cultivation into cacao and to (ii) satisfy an industry's desire for new flavors, which are usually associated with premium prices [28-30].

The Peruvian government and the international community have been undertaking efforts to reduce illegal coca plantations in the country for many years, aiming to reduce the total coca harvest through crop substitution and skills development programs [27,31]. However, given the Peruvian government's limited institutional reach in remote areas, the threat of violence associated with illegal activities and, more importantly, the long period of time for these substitute crops to produce incomes for farmers, there remains a risk that many smallholders will fall back into coca production. Consequently, the fight against this illegal activity needs to be reconceived.

Accordingly, the sweet spot for creating shared value could be a country-specific response to both the concerns of the Peruvian Government and the international community regarding drug trafficking and to the needs of the chocolate industry as expressed by global manufacturers, processors and traders. The sweet spot could be structured to reduce poverty and eradicate illegal coca plantations by providing small farmers a sustainable and profitable alternative source of income. In so doing, it can address some of the chocolate industry's major challenges by improving the living standards of cacao farmers, incorporating new farmers into the value chain of cacao and providing access to the much- 
sought-after new flavors and profiles of sustainable cacao. Thus, the sweet spot provides intertwined social and economic benefits at local, national and international levels.

It is in this context that a global trader of cacao, Armajaro Trading (Armajaro Trading was acquired by ECOM in November, 2013), identified an opportunity for applying for USAID funds under the Global Development Alliance (GDA) Program. Armajaro is principally an integrated trading company, involved in buying from farmers, primary manufacturing, logistics services and selling to global chocolate firms. As such, Armajaro is in an important position to identify important gaps and opportunities for improvement in the value chain but not necessarily in the position to structure nor finance the complex solutions needed to solve and leverage the potential opportunities identified. Therefore, to further the opportunity, Armajaro required an experienced partner that routinely dealt with such problems to develop and implement the proposal for obtaining international development funding by USAID. It therefore sought the assistance of the CARANA Corporation (The CARANA Corporation is part of the Palladium Group), which has significant experience structuring and running collaborative development projects. Thus, the eventual proposal involved a large-scale public-private partnership with members from different sectors across the value chain stemming from the Peruvian production of cacao.

In October 2012, following a successful bid, CARANA signed a cooperative agreement with USAID and created the multi-stakeholder platform (MSP) named the "Peru Cacao Alliance" (PCA) in order to manage the program and orchestrate the efforts of these multiple partners. USAID committed USD 36 million with the condition that the project raises contributions from private and Peruvian government sources. CARANA secured USD 43 million from the private sector, with the Peruvian Government contributing USD 6.5 million. A total of USD 85.5 million was committed to the four-year project (20122016). The PCA's most important private investors were the cacao traders Armajaro and another local trading group Romex (part of the Romero business group, a leading Peruvian cacao exporter), which contributed USD 6.4 million and USD 5.9 million, respectively. One of the key aspects of the project was the link with global brands of chocolate. Both Armajaro and Romex provided the means for obtaining this objective. While Armajaro has stronger links with global brands, Romex has a better understanding of Peruvian farming practices, distribution and local customers. In addition, a number of financial institutions, farmer cooperatives and producer organizations were also invited to participate, all of which assisted in developing a supply chain to support crop substitution from illegal coca production into fine-flavor cacao varietals by providing not only assistance and training in good farming practices but also in securing financial and technical resources to back up the transition. The project's goals were to integrate 23,000 small-scale farmers and a further 28,000 hectares into the global cacao supply chain, to generate 18,000 new jobs in the sector and to connect 10,000 families to the necessary financial services to effect the plan. Figure 1 provides a map of the PCA's stakeholders, while Table 1 provides a summary of the organizations involved in the project, with the interests and type of resources each brings to the alliance.

Michelini and Fiorentino [32] supported the development of a framework similar to that featured in Table 1. They also suggested that social and inclusive business models could be considered similar to the ones pursued by for-profit organizations to innovate distribution models and to use knowledge around productive value chains, though the authors note that these business models will differ in terms of their value propositions, governance, social risk and profit equations.

\subsection{Creating Shared Value: Main Tenets and Criticisms}

Porter and Kramer $[19,20]$ proposed that it is possible to simultaneously create societal and economic value and they coined the term Creating Shared Value (CSV) to identify the policies and operating practices that improve the competitiveness of a company while at the same time forwarding the economic and social conditions of the communities in which the company works [20]. To implement, they identified that firms willing to adopt 
CSV have three main mechanisms: (i) to reconceive products and markets, (ii) to redefine productivity in the value chain and (iii) to enable cluster development.

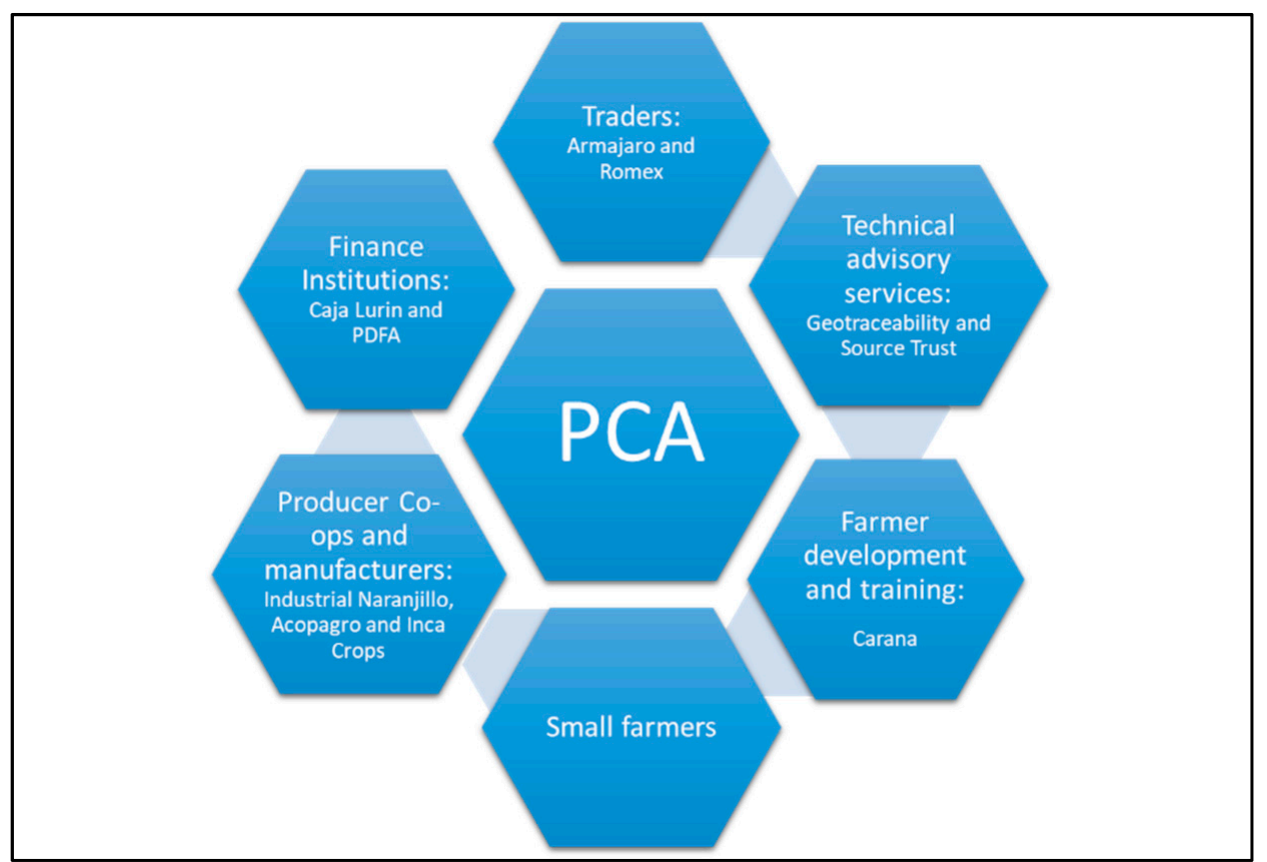

Figure 1. Stakeholder map of the Peruvian Cocoa Alliance.

Table 1. Stakeholder interests and resources brought to the shared value alliance.

\begin{tabular}{|c|c|c|c|}
\hline Stakeholder Group & Entity & Interests & Resources \\
\hline Peruvian Cacao Alliance & & $\begin{array}{l}\text { To achieve project outcomes } \\
\text { on time and within budget }\end{array}$ & $\begin{array}{l}\text { Central to the alliance's } \\
\text { operations, brings together } \\
\text { partner governance and } \\
\text { provides operational } \\
\text { oversight and management }\end{array}$ \\
\hline \multirow{2}{*}{ Traders } & Armajaro & $\begin{array}{l}\text { To improve its access to } \\
\text { high-quality Peruvian cocoa }\end{array}$ & $\begin{array}{l}\text { Significant cocoa trader with } \\
\text { strong connections to } \\
\text { international cocoa markets } \\
\text { and manufacturing companies }\end{array}$ \\
\hline & Romex & $\begin{array}{l}\text { To improve access to } \\
\text { high-quality Peruvian cocoa }\end{array}$ & $\begin{array}{l}\text { Significant local cocoa trader } \\
\text { with strong local } \\
\text { networks and } \\
\text { transportation coordination }\end{array}$ \\
\hline \multirow{2}{*}{ Technical Services } & Geotracibility & $\begin{array}{l}\text { To extend their geolocation } \\
\text { services footprint }\end{array}$ & $\begin{array}{l}\text { Experience and technical } \\
\text { abilities provide large-scale } \\
\text { mapping and geolocation data } \\
\text { for product tracing and } \\
\text { certification purposes }\end{array}$ \\
\hline & SourceTrust & $\begin{array}{c}\text { To develop, implement, } \\
\text { operate and provide training } \\
\text { on the agroforestry system } \\
\text { used by the PCA }\end{array}$ & $\begin{array}{l}\text { Experience and technical } \\
\text { abilities in agroforestry } \\
\text { design, operations and } \\
\text { training on a large scale across } \\
\text { various crops and locations }\end{array}$ \\
\hline
\end{tabular}


Table 1. Cont.

\begin{tabular}{|c|c|c|c|}
\hline Stakeholder Group & Entity & Interests & Resources \\
\hline \multirow{2}{*}{ Funders } & USAID & $\begin{array}{l}\text { To reduce reliance on illicit } \\
\text { drug production within } \\
\text { funding criterion }\end{array}$ & $\begin{array}{l}\text { Provides funds through a } \\
\text { bilateral aid program and sets } \\
\text { boundaries for project } \\
\text { conduct and progress }\end{array}$ \\
\hline & Peruvian Government & $\begin{array}{c}\text { To improve Peruvian citizen's } \\
\text { lives through reducing } \\
\text { reliance on illicit } \\
\text { drugs production }\end{array}$ & $\begin{array}{l}\text { Promotes crop substitution } \\
\text { and alternative livelihoods } \\
\text { and provides coordination } \\
\text { across Peruvian } \\
\text { government entities. }\end{array}$ \\
\hline Farmer Development & CARANA & $\begin{array}{l}\text { To improve client farmer } \\
\text { productivity and profitability }\end{array}$ & $\begin{array}{l}\text { Significant experience in small } \\
\text { farmer networks providing } \\
\text { appropriate and } \\
\text { accessible capacity } \\
\text { development programs }\end{array}$ \\
\hline Farmers (Beneficiaries) & & $\begin{array}{l}\text { Small scale farmers involved } \\
\text { in small scale coca production } \\
\text { or at risk of coca production }\end{array}$ & Land and labor \\
\hline \multirow{2}{*}{$\begin{array}{l}\text { Producer Co-ops and } \\
\text { Manufacturers }\end{array}$} & Naranjillo & $\begin{array}{l}\text { To utilize high-quality } \\
\text { Peruvian cocoa in their } \\
\text { chocolate products }\end{array}$ & $\begin{array}{c}\text { Manufacturing, distribution } \\
\text { and marketing experience and } \\
\text { networks for } \\
\text { chocolate products }\end{array}$ \\
\hline & Inca Crops & $\begin{array}{l}\text { To utilize the project's } \\
\text { secondary crops }\end{array}$ & $\begin{array}{c}\text { Domestic snack food product } \\
\text { production capability and } \\
\text { marketing networks }\end{array}$ \\
\hline Regional government & & $\begin{array}{l}\text { To govern and improve local } \\
\text { economic opportunities }\end{array}$ & $\begin{array}{l}\text { Local governance and } \\
\text { administrative networks } \\
\text { and contacts }\end{array}$ \\
\hline \multirow{2}{*}{ Finance Institutions } & Caja Lurin & $\begin{array}{l}\text { To provide access to credit } \\
\text { and savings opportunities by } \\
\text { the cooperative members }\end{array}$ & $\begin{array}{l}\text { Local presence and oversight } \\
\text { of lending, debt management } \\
\text { and saving opportunities for } \\
\text { rural people }\end{array}$ \\
\hline & PDFA & $\begin{array}{l}\text { To improve access to } \\
\text { microfinance and financial } \\
\text { capabilities of small } \\
\text { business owners }\end{array}$ & $\begin{array}{l}\text { Provides access to } \\
\text { microfinance funds, loan } \\
\text { guarantees and financial } \\
\text { training for lenders }\end{array}$ \\
\hline
\end{tabular}

Source. Authors.

Reconceiving products and markets refers to a focal firm that improves the overall quality of the products offered by either minimizing the impact on the environment or facilitating access for disadvantaged others. Redefining productivity in the value (supply) chain involves the focal firm responding to either environmental or societal problems that are affecting its own efficiency. By addressing these problems, the focal firm would innovate through, for instance, reducing the use of (non-renewable) resources, by improving procurement processes or by enhancing employee productivity, thus having a direct impact on its own costs. Lastly, enabling cluster development entails the focal firm building or incenting a supportive cluster around its own activities, which increases its positive impact on the communities in which it operates or improves general framework conditions that otherwise constrain or limit the capacity of the cluster to generate value [20].

CSV is not without controversy. Despite Porter and Kramer [19,20] having recognized that firms may require partnerships to pursue CSV initiatives, their initial emphasis has been on the capacity of the focal firm and its strategies to simultaneously pursue social and economic benefits. Dembek et al. [21] highlighted certain shortcomings associated with this conceptualization of CSV, arguing that it neglects a systemic perspective about 
not only the needs that require addressing (and their beneficiaries) but also the actors that are required to simultaneously pursue these two types of gains, despite the model anticipating roles for and impacts on others. Further, Crane et al. [22] argued that CSV ignores the tensions inherent in responsible business activity and note that this principle is naive regarding business compliance, questioning the idealistic conceptualization of corporations and their capacity to simultaneously address the CSV goals given the inherent tradeoff associated with pursuing societal and/or environmental goals and economic goals at once. In fact, Crane et al. [22] argued that firms pursuing these two types of goals are most typically involved in solving ethical dilemmas and brokering tradeoffs and not in merely implementing details associated with win-win situations.

More recently, Kramer and Pfizer [33] contend that firms need to work in coalitions to pursue CSV goals and address complex social problems. Thus, they have moved from a firm-only conceptualization of addressing social and environmental complications while achieving economic progress to recognizing that companies face barriers that are beyond their control and that these complex problems require coordinated action among different actors to obtain a "collective impact" ([33], p. 6). The authors assert that it is necessary that partners hold a common vision and agenda, establish a shared measurement system to evaluate progress and success, pursue mutually reinforcing activities based on partner strengths, have constant communication to build trust and legitimacy, and finally, they need to constitute a dedicated backbone of support independent of each partner to obtain the collective impact. Taking this view, CSV reflects more of a stakeholder model of value creation [23].

Central to this multi-stakeholder platform [34] model of value creation is the development of trust between supply chain partners, which underpins the basis for long-term relationships and reduces risks from opportunistic behavior [35]. Through an exhibition of reputation-enhancing behavior, trust can be built, and from this, the diverse parties can credibly anticipate long-term business and social success. This is important for international supply chains, where reputational trust leads to strong beliefs between parties that joint decisions and solutions for problems will benefit all, allowing for an atmosphere of innovation [36].

In spite of its importance, previous empirical research has treated trust among partners as a given, with the studies mainly focusing on the benefits that can be obtained through CSV efforts. However, sharing a vision or goals is insufficient for generating a frictionless alignment among partners. In fact, Crane et al. [22] were critical that most of the empirical evidence associated with CSV largely ignores any tensions between partners while social and economic progress is being pursued. In addition, the existence of competitive free riders has been acknowledged [33], while most research pays little attention to the costs involved in effecting these partnerships [21], both of which have the potential to directly affect business performance.

Even though the CSV concept has been criticized both theoretically and empirically, it has increasingly captured the interest of and has been adopted by large corporations [33]. The CSV value proposition of aligning societal and business value creation remains of interest but requires far more evidence to proffer clear guidance for how firms might interpret and implement CSV in their relevant business environments [21,23].

\subsection{Methodological Approach}

To develop this case, we selected qualitative methods, which is an approach to research that explores the meanings individuals or groups give to a social or human problem, through processes of questioning, theme building and interpretation as opposed to theory testing using numerical data, which is the hallmark of quantitative studies [37]. As we are interested in understanding how the alliance can into effect, its organization and re-design of relationships, we considered qualitative methods to be suitable for gaining a better understanding of the processes and decisions found in this part of the Peruvian cacao value chain and between the members of the PCA (see Figure 1 and Table 1 presented previously). 
We decided to apply the case study method following Hogevold and Svensson's [38] call for the use of more inductive research in the field of sustainability and as it is considered to be an appropriate approach to describe the experience of the PCA in detail within its relevant context $[39,40]$. Thus, we have a multi-stakeholder approach to analyze the complex nature of this alliance organization and its multiple collaborators simultaneously pursuing societal and business gains.

For more clarity, we consider it convenient to present here a brief description of the PCA's value chain and the role of its key stakeholders (Figure 2). Regarding the primary activities, SourceTrust was in charge of the inbound logistics by providing high-quality cocoa tree seedlings, banana clones and timber wood trees to small farmers. Later, CARANA Corporation replaced SourceTrust and involved local municipalities to provide these materials. In the operations, the key actors were the farmer, cooperatives (i.e., Acopagro) and local manufacturers (i.e., Industrial Naranjillo). The outbound logistics were in charge of cooperatives, Armajaro Trading and Romex. Depending on the stage of the project, the marketing and sales were in charge of different stakeholders. At early stages, Inka Crops was in charge of acquiring the bananas associated with the agroforestry system. Once the cacao plants were mature, the role of marketing and sales were in charge of Romex and Armajaro trading. Finally, the role of service was mainly in charge of companies that commercialized the cacao. It is important to note that the PCA monitors and provides support for all the links of the chain.

Firm Infrastructure: Financial resources at the project level: USAID, Peruvian Government, Armajaro Trading and Romex. At the farmer level: PDFA, Microfinance institutions: Caja Luren).

Human Resources: PCA provides most of the staff to supervise the program. Each stakeholder provides their own in each link of the chain.

Technology Development: In charge of Source Trust (Agroforestry systems), Carana Co, Geotraceability and PCA.
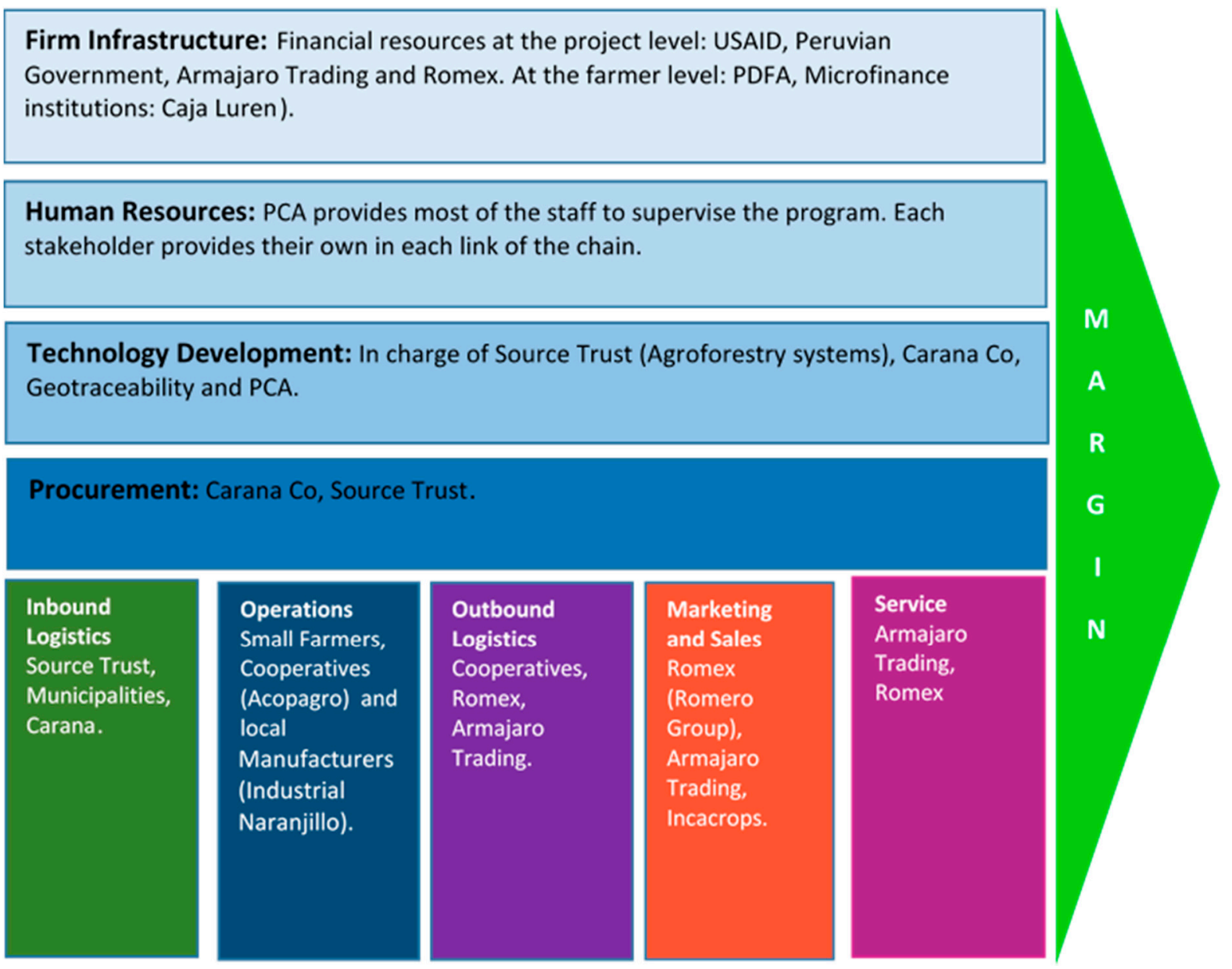

Figure 2. Peru Cacao Alliance's Value Chain.

Regarding the supporting activities, financial resources represent an important aspect to describe in infrastructure. At the project level, USAID, the Peruvian government, Armajaro trading and Romex were responsible for backing up almost the entire operation. 
At the farmer level, PDFA and microfinance institutions (i.e., Caja Luren) were important to provide financial advice and resources to farmers. Most of the staff associated with the management, monitoring and control of the project was in charge of the PCA. However, each stakeholder was responsible for providing its own staff in the links of the chain in which they participated. SourceTrust and Geotraceability provide the technology needed in the project. The former created the agroforestry system to be implemented by the farmer, and the latter provided geolocalization to secure the traceability of the cacao. Both of them were replaced at later stages of the project. CARANA Corporation replaced the role of Source Trust and the PCA team internalized the services provided by Geotraceability. Finally, the procurement was provided by Source Trust and CARANA.

\subsubsection{Data Gathering}

We used two forms of data. The first was from interview data gathered from a previous research project [41]. The interview is a research method that allows researchers to collect in-depth information about a topic and that allows respondents to provide relevant information regarding their experiences and domains of knowledge [42]. The three main objectives of these interviews were to understand (i) the actors' motivations for their participation in the Peruvian cacao/chocolate value chain and in the PCA, (ii) specific details surrounding the configuration of a new value chain within the Peruvian cacao industry relative to the more traditional production chain that the producer communities formerly participated in and (iii) the identification of problems experienced among PCA's partners during the project. Accordingly, this data collection process allowed us to identify which strategies were used by the PCA and to ascertain the mechanisms of shared value creation and the conflicts faced during the implementation of those strategies. The second data form was gathered through the analysis of annual reports and other printed materials to triangulate interview data and to augment our understanding of the alliance.

We re-analyzed 22 internal value chain actor interviews (see Table 2) and 7 external actor interviews (see Table 3). We undertook an additional 3 interviews with key informants from CARANA, Amajaro and the PCA in 2019 to fill data gaps and to provide more recent perspectives on the progress of the PCA since the first set of interviews. These additional interviews provided additional data and insights that were not available from the previous interviews and cast new light on the processes of the inter-alliance relationships, conflict and exits from the alliance. Purposive sampling [43] was chosen to select the respondents for their relevant information, which they can provide with respect to the situation under study [44]. The respondents were selected based on their position, knowledge of alliance and project relationships and availability. From the range of perspectives provided by the respondents, we were able to develop a coherent and more comprehensive picture of the PCA and the outcomes that it generated.

Table 2. Interviews with internal alliance actors.

\begin{tabular}{ccc}
\hline Interview ID & Position or Role & Actor \\
\hline 1 & Manager & Acopagro \\
2 & Director & PCA \\
3 & Regional Director of San Martín & PCA \\
4 & Regional Director of Huánuco & PCA \\
5 & Monitoring and Evaluation of San Martín & PCA \\
6 & Agribusiness Manager of San Martín & PCA \\
7 & President & PDFA \\
8 & Responsible for the three PDFA regions & PDFA \\
9 & Financial Services Specialist, Office Manager and Credit Analyst & PDFA, Caja Luren \\
\hline
\end{tabular}


Table 2. Cont.

\begin{tabular}{ccc}
\hline Interview ID & Position or Role & Actor \\
\hline 10 & Head of Sustainable Cocoa & Armajaro Trading \\
11 & Head of Latin America & Armajaro Trading \\
12 & Regional Coordinator & Armajaro Trading \\
13 & Quality Manager of San Martín & Armajaro Trading \\
14 & Agribusiness and Environment Manager and Specialist in value chains, & CARANA Co. \\
15 & consultant specialized in agribusiness & CARANA Co. \\
16 & Head of the Monitoring and Evaluation Area & CARANA Co. \\
17 & Director of the PCA & Industrial Naranjillo \\
19 & General Manager Cooperativa Agraria & Geotraceability \\
20 & Regional Manager for the Americas & Inka Crops \\
21 & Head of Marketing & Exporter Romex \\
22 & General Manager & SourceTrust \\
USAID
\end{tabular}

Source. Authors.

Table 3. Interviews with experts and external alliance actors.

\begin{tabular}{ccc}
\hline Interview ID & Expertise of the Interviewee & Actor \\
\hline 1 & Agribusiness expert & National Coffee Board \\
2 & Agribusiness Compensation Program & Ministry of Agriculture \\
3 & Commerce and marketing related to chocolate & Consulting Group \\
4 & Cocoa quality control specialist & Cocoa Technical Table \\
5 & Cocoa production chain specialist & Regional Government San Martín \\
6 & Management and improvement of the cocoa value chain & Local trainer \\
\hline
\end{tabular}

Source. Authors.

\subsubsection{Coding and Measures}

According to the CSV concept, shared value is created through the mechanisms of; (i) reconceiving products and markets, (ii) redefining productivity in the value chain and (iii) enabling local cluster development [20]. Using these three categories as an analysis frame, we applied content analysis, a process of categorizing qualitative textual data [45], to the interviews in order to identify data related to these CSV themes. Content analysis is commonly used for analyzing a wide range of textual data, including interview transcripts, which typically produces clusters or codes that translate into themes [45]. We also used the interview data to track the sequencing of alliance activities among actors in order to develop a draft case narrative. Table 4 provides a summary of the coding categories and the criteria used for analyzing the interview data. We read the transcripts and deductively identified, categorized and organized the data according to the themes of Porter and Kramer's three main mechanisms [20].

Table 4. Creating economic value through social value.

\begin{tabular}{|c|c|c|}
\hline Creation Method & Description & Key Elements \\
\hline & Ensuring the product is good for customers & It has no negative effects or attributes \\
\hline Reconceive products and markets & Addressing the needs of underserved markets & Meets customer needs and social benefits \\
\hline Redefine productivity in the value chain & $\begin{array}{l}\text { Identify and mitigate internal and external } \\
\text { value chain costs } \\
\text { Explicitly establish the link between societal } \\
\text { progress and productivity }\end{array}$ & $\begin{array}{c}\text { Areas for gain are energy use and logistics, } \\
\text { resource use, procurement, distribution and } \\
\text { employee productivity }\end{array}$ \\
\hline Enable local cluster development & $\begin{array}{l}\text { Identify cluster potentials and capabilities } \\
\text { Reliance on networks of partnerships }\end{array}$ & $\begin{array}{l}\text { Partners can be related businesses, } \\
\text { infrastructures and public institutions }\end{array}$ \\
\hline
\end{tabular}


From the analysis of interviewee experiences and actions, we were able to identify the corresponding elements to reveal how shared value was created in this case. These results are discussed further in the next section.

\section{Results and Discussion}

\subsection{Reconceiving Products and Markets}

The Peru Cacao Alliance (PCA) aims to reconceive products and markets by proposing a new (genetic) variety of cacao in the market backed with an innovative agroforestry system required to support adequate growth of the crop and a traceability system to promote the identification of the farmers and the quality produced by each. All these characteristics should help farmers obtain premium prices for their cacao beans while addressing the needs of the chocolate industry.

Considering the complexity of the social, environmental and business needs to be addressed, this project required the formation of an "ecosystem of shared value" ([33], p. 3) where all actors could be aligned to previously defined common goals and where the strengths of each partner can be leveraged.

In this sense, to select the type of cacao that the project should embrace, the PCA relied on Armajaro's previous expertise as a global trader of cacao and its strong relationships within the chocolate industry. According to Armajaro, competing with African countries in bulk cacao was not feasible given the volumes and cost structures obtained in other major countries such as Ivory Coast and Ghana. Instead, Peru presented the opportunity to differentiate itself in the marketplace by leveraging its cacao biodiversity to offer fine-flavor cacao varieties.

The public-private partnership idea of Armajaro was aligned with demand-side expectations associated with major chocolate customers. The global demand for fine-flavor cacao has grown rapidly in recent years and while traded in commodity markets, these fineflavor varieties command a premium price over bulk cacao [47], with chocolate companies willing to pay up to 3 times more per ton of fine flavor over that paid for bulk [48].

However, fine flavor cacao is difficult to grow, is more susceptible to disease, requires more investment on the part of the farmer, and while a farmer's income is intended to be from fine-flavor cacao, it will be two to three years before any income may be received. To address these difficulties, the PCA accepted the proposal of Armajaro and SourceTrust to design and implement a mixed agroforestry system, which would support the establishment of fine flavor varieties. This proposal was designed to integrate a variety of crops with different maturity horizons so as to provide a range of income sources for the farmer over the cacao crop establishment period, promoting environmental and biodiversity outcomes while minimizing the impact on the environment, including reducing land erosion. For the short term, banana is often used during the first three years of cacao pre-harvest growth as it provides shade, reduces adverse weather effects and addresses soil nutritional imbalances while providing cash to farmers relatively quickly. For the long term, the new agroforestry system also includes timber trees. These add a biodiversity bonus and a potential future income over a longer time horizon. Cacao incomes in the middle term represent the most important income benefit for participating farmers.

A third PCA aspect associated with the re-conception of products and markets was the inclusion of a traceability system. Tracing relates to two issues: (i) reputational risks associated with the choices and decisions of farmers; and (ii) the issue of provenance, or proof of specific cacao bean source, which is necessary owing to the presence of multiple intermediaries interacting with various producers such that fine-flavor cacao beans often become co-mingled with bulk cacao beans, reducing the quality of the resulting offering and inhibiting access to premium prices [49].

The PCA's cacao tracing allows chocolate manufacturers to directly identify from which farms the cacao lots have been obtained to validate varietal, biodiversity conditions as well as the living conditions of the farmers in these lots. The PCA's first tracking system was instituted by project partner, Geotraceability Ltd., which topographically mapped 
the project's 28,000 hectares and gathered relevant socioeconomic data about the farmers and their living conditions. Instituting crop tracing has had the effect of encouraging the farmers to certify their crops as a means of more consistently obtaining premium prices for their high-quality cacao beans, improving their overall margins.

In contrast with most development programs where farmers are treated only as grant beneficiaries and receive products and services without charge, the PCA sought to treat its farmers as co-investors in an enhanced cacao supply chain and CSV system. Consequently, the farmers were also required to bear part of the initial project's costs. A significant cost for farmers is associated with land preparation, representing approximately $50 \%$ of the initial costs required to expand cacao production [50]. Farmers also bought and planted the seeds for the agroforestry system's banana trees and contributed by underwriting a grafting service for the cacao. The grafting service process was undertaken by the early entrants providing cuttings from their established cacao plants to be grafted by later entering farmers onto regular cacao trees, thus enabling them to produce fine-flavor cacao varieties. It is estimated that the PCA's farmers invested an equivalent of USD 28 million through these three mechanisms [50].

\subsection{Redefining Productivity in the Value Chain}

As indicated before, to attain the sweet spot, there are critical needs for farmers and for commercial players in the chocolate industry that must be addressed. On the farmers' side, it was important to support their capacity to create business value. It was not enough to rely on quality products with premium prices because fine-flavor cacao has a very economically attractive (albeit illegal) substitute crop, the cultivation of coca. From the farmer's point of view, there are several advantages associated with coca cultivation such as the short cultivation period (less than one-year yield period), its cash-on-delivery payment regime and the low investment required to produce it. Therefore, there is an ever-present risk of farmers returning to producing the illicit crop. The PCA aimed to reduce this risk. On the chocolate industry side, the project aims to provide not only new cacao profiles and flavors to premium price-paying markets but to also provide the assurance of traceability to reduce reputational problems faced by global brands. Consequently, the PCA aims to improve the traditional procurement process in the cacao industry by (i) assuring a new short-term income to farmers, (ii) improving farmer capabilities and (iii) providing access to financial services. These mechanisms are described next.

First, despite the positive expectations in the medium-term (income from cacao) and long-run (income from timber), the PCA needed to secure a market for the new short-term crop of bananas. The PCA's response was to secure the participation of Inka Crops, a leading Peruvian company specializing in the production, distribution and sale of gourmet snacks, which include banana/plantain chips. Hence, by selling their bananas to Inka Crops, farmers could obtain short term economic benefits while providing their developing cacao plants with favorable (i.e., shaded) growing conditions. Similarly, in the medium to long-run, the PCA assured relatively direct access to international cacao markets with its trader partners. Armajaro and Romex, who are Peru's most important cacao brokers, provide storage, transportation and payment for fine-flavor cacao through their own local community-based representatives, whose involvement also acts to reinforce trust between the project and its farmers.

Second, the PCA has worked extensively on providing advice and access to best-inthe-world farming practices in order to enhance trust and to develop farmer capabilities. CARANA has developed specific expertise to develop small-scale agribusinesses and as such has become increasingly responsible for improving the PCA's production by educating the farmers about land preparation, planting, growing and harvesting techniques and preparation procedures. In addition, CARANA helps identify additional acreage that farmers may be able to further devote to cacao production. All of these collaborative activities are conducted without formal contracting and have been nurtured through the PCA's relational capital gained over the years. 
Finally, it was necessary to review and reconstitute access to financial services. Typically, Peruvian smallholding farmers tend not to have access to the formal financial system and are unable to get financing at the market rates that other commercial borrowers can obtain. When credit is extended to them, it tends to be at very high rates, which are prohibitively costly given the economics inherent in this smallholder scale of farming in Peru. In response, the PCA now facilitates access to crop financing for the farmers, which is necessary for this value chain reconfiguration. This financial facilitation is achieved in partnership with the Peruvian Development Finance Association (PDFA), which is responsible for securing microfinance institution participation and promoting financial literacy issues for the PCA participant farmers. The PDFA channels institutional and development bank funds through microfinance institutions to the smallholding farmers using the mixed agroforestry system. Due to the early involvement of governmental partners, the PDFA was able to provide collateral up to $50 \%$ of a loan, which minimized the risk assumed by farmers, fostering greater access to credit.

\subsection{Enabling Cluster Development}

In order to reconceive products and services provided and to redefine productivity in the value chain, the PCA needed to enable cluster development in the remote zones where cacao is cultivated. From inception to implementation, the PCA had been including a diverse array of interconnected partners, which include Peru's top cacao traders, technical advisory services, financial institutions, producer cooperatives and processors, municipalities and the Peruvian government, through the National Commission for Development and Life without Drugs (DEVIDA).

Members of the PCA began by developing a common understanding of the goals to be accomplished. The PCA has effectively combined the interests of the Peruvian government and the international development community (in their fight against illegal coca plantations and promotion of sustainable livelihoods) and private companies associated with the chocolate industry. While the potential for conflict existed, the PCA built upon its key stakeholder's strengths and resources in order to address other stakeholders' concerns. Even with this extensive preparation, conflicts over implementation led to the founding members Armajaro and SourceTrust leaving the PCA after only two years of operations.

Initially, SourceTrust played a role in the PCA of bringing the technology associated with agroforestry systems and investing in building a production center with several distribution facilities near the main growing areas of cacao in Peru. SourceTrust also provided training and ongoing assistance to the PCA's field technicians, facilitating the project's cultivation knowledge transfer. However, the PCA's view was that this solution was more suitable for large plantations and not effective for smallholding farmers who were proximally distant and in locations that were difficult to access. Moreover, the PCA believed the method pursued by SourceTrust was contributing to project delays, through underestimated transportation challenges and budgetary issues.

In light of these issues, the PCA explored an alternative course of action. CARANA had been operating in Peru since 2002 in other development programs with small farmers working in concert with local governmental entities. Since municipalities in the project area were fairly responsive to reforestation initiatives, they showed early interest in participating. Despite the common goal among partners, there were misalignments on the course of action needed to reach the goals of the PCA. While CARANA favors leveraging the interests of local governments, Armajaro believed a better strategy was to maintain control over the project's processes. Consequently, realigning the originally programmed arrangements proved more difficult than expected, leading to Armajaro and SourceTrust's departure from the Alliance.

In addition to Armajaro and SourceTrust, Geotraceability soon left. Despite cacao tracking being a key component of the value proposition, the PCA decided to internalize these functions by developing its own traceability solution. The main problem with Geotracibility's original solution was the long time required to update the system, which 
could have jeopardized the potential benefits that farmers could obtain. As a result, the PCA now manages its own dataset of 17,000 farmers, maintaining information on farmer plot locations, dimensions, and production capacities.

The PCA also encouraged the formation of small associations of farmers. These self-organizing groups of twenty to thirty farmers aimed to ease the distribution of raw materials, fertilizers and training and to assist with coordinating harvesting, pricing and adopting common payment dates.

According to the Peru Cacao Alliance [49], the GDA-funded project incorporated more than 29,000 hectares of cacao, created more than 20,000 jobs, provided more than 4000 of families with access to finance and introduced almost 16,000 hectares of new cacao trees using its agroforestry system. Given these results, the PCA obtained a second round of financing with USAID, which is targeted to further improve the productivity of the fine flavor cacao crop already incorporated in the value chain in the future.

\section{Conclusions, Contributions and Avenues for Future Research}

In this analysis, we aimed to address several of the shortcomings highlighted in the literature regarding how firms approach and implement CSV strategies in practice. To the best of our knowledge, this case is one of few that consider a multi-stakeholder perspective by including interviews with partners of the alliance and with industry experts. Our approach therefore supports the conception of CSV as a stakeholder model of value creation suggested by Corazza et al. [23].

By analyzing the PCA's experience using the CSV perspective, we are able to better understand the needs of different stakeholders and to identify the tensions that exist around exploiting opportunities in the sweet spot—conflicts which the literature normally ignores [22]. Further, we identify not only the potential benefits that can be obtained by different supply chain partners but also indicate the range of costs that these partners have to bear in order to participate in the alliance [21].

While addressing social and business gains remains fairly attractive for the business community, it is necessary to stress that a common vision or goals do not guarantee a successful implementation of CSV strategies. While careful planning is important, it appears even more important to also assume that conflicts among partners will be present during the implementation process. Therefore, it is necessary to have some flexibility in order to address issues that may not have been identified in the original planning and project design. Moreover, it is necessary that partners understand that despite their positive intentions and strategies conceived to address social problems at a profit, unforeseen issues, such as the ones described here, could create tensions among them. This would require the re-evaluation of the attractiveness of certain pre-established actions and would require alternative paths that would affect the anticipated outcomes at the firm level. In our case, the PCA orchestrates the efforts of multiple partners and has the capacity to decide on the proper use of the resources available to reach the goals, and this orchestration role at the alliance level proved to be determinant in this regard. When developing a project like this, it would be wise to establish exit mechanisms in advance in case partners decided to leave. By understanding the risks assumed by each firm and their rights during project execution, participant engagement can be better clarified around the joint pursuit of environmental/societal and business value.

There are also several managerial implications associated with this work. First, rather than considering poor people only as beneficiaries of some sort of valuable resource, managers need to consider them as co-investors in the project. Managers should be aware that free resources or assets do not compromise people. In our case, farmers needed to prepare their lands on their own in order to receive support from PCA. Investment of some kind could be decisive to align the interests of different parties. Second, managers should develop capabilities on their stakeholders to improve productivity, reliability and efficiency. At the PCA, including training in best farming practices was important in order to obtain both a reliable source of cacao and an increased source of income for the farmer. Third, 
managers need to encourage the formation of alliances, networks or associations because it eases coordination, facilitates learning and creates a sense of community.

As this work is based on a multi-stakeholder case study, the results presented here are not fully generalizable to new stakeholder configurations in this or other industries, though they do point to the challenges and provide an enhanced understanding of the relative strengths and weaknesses of the redesign approach. There are also some directions for future research that emerge. For instance, given the characteristics of the project, in that it received seed funding from USAID, future research may wish to examine the feasibility of developing CSV strategies without including development agencies, for it is not clear how the process would progress in the absence of these agencies' binding and stabilizing influences. Nor is it clear how their involvement influences trust creation across participants.

In conclusion, both Gabler et al. [18] and Illge and Preuss [51] indicate that firms struggle to simultaneously address societal and economic progress. We believe that, by analyzing the experience in the cacao value chain in Peru by using the CSV framework proposed by Porter and Kramer [19,20], we have offered some practical advice and insight into how to begin to redesign supply chains for sustainability and into using the CSV approach and, in so doing, provide an initial step towards the better understanding of the CSV concept in practice and its boundary conditions.

Author Contributions: Conceptualization, A.B., O.M. and H.T.; Methodology, A.B., O.M. and H.T.; Investigation and Formal Analysis, A.B. and O.M.; Writing-Original Draft Preparation, A.B., O.M., M.A.G.-P. and G.H.R.; Writing-Review and Editing, H.T., G.H.R. and M.A.G.-P. All authors have read and agreed to the published version of the manuscript.

Funding: This research received no external funding.

Institutional Review Board Statement: The study was conducted according to the guidelines of the Declaration of Helsinki, and approved through the Ethics/Research Proposal procedures of the Graduate School of Business, Universidad ESAN (24 January 2014).

Informed Consent Statement: Informed consent was obtained from all subjects involved in the study.

Data Availability Statement: The data presented in this study are available on request from the corresponding author. The data are not publicly available due to confidentiality.

Acknowledgments: The authors would like to acknowledge the work of Andrés Argandoña, Remy Farach, Lenny Garcia Naranjo and Katia Lazo, whose Master's thesis provided the inspiration to develop this article.

Conflicts of Interest: The authors declare no conflict of interest.

\section{References}

1. Abesamis, A. 8 Unbelievable Facts about the $\$ 103$ Billion Chocolate Industry; Insider: Indianapolis, IN, USA, 2019. Available online: https:/ / www.insider.com/chocolate-industry-facts-statistics-consumption-2019-11 (accessed on 14 June 2020).

2. Technavio. Global Chocolate Market 2019-2023; Technavio: London, UK, 2018. Available online: https:/ / www.technavio.com/ report/global-chocolate-market-industry-analysis (accessed on 26 June 2019).

3. Euromonitor. Market Sizes_Chocolate Confectionary; Euromonitor International: London, UK, 2019. Available online: https: / / www.portal.euromonitor.com/portal/statisticsevolution/index (accessed on 26 June 2019).

4. Castañeda-Ccori, J.; Bilhaut, A.-G.; Mazé, A.; Fernández-Manjarrés, J. Unveiling Cacao Agroforestry Sustainability through the Socio-Ecological Systems Diagnostic Framework: The Case of Four Amazonian Rural Communities in Ecuador. Sustainability 2020, 12, 5934. [CrossRef]

5. Zarrillo, S.; Gaikwad, N.; Lanaud, C.; Powis, T.; Viot, C.; Lesur, I.; Fouet, O.; Argout, X.; Guichoux, E.; Salin, F.; et al. The use and domestication of Theobroma cacao during the mid-Holocene in the upper Amazon. Nat. Ecol. Evol. 2018, 20182, 1879-1888. [CrossRef] [PubMed]

6. Marelli, J.P.; Guest, D.; Bailey, B.A.; Evans, H.C.; Brown, J.K.; Junaid, M.; Barreto, R.W.; Lisboa, D.O.; Puig, A.S. Chocolate Under Threat from Old and New Cacao Diseases. Phytopathol. Rev. 2019, 109, 1331-1343. [CrossRef] [PubMed]

7. Naranjo-Merino, C.A.; Ortíz-Rodriguez, O.O.; Villamizar-G, R.A. Assessing Green and Blue Water Footprints in the Supply Chain of Cocoa Production: A Case Study in the Northeast of Colombia. Sustainability 2018, 10, 38. [CrossRef] 
8. Reuter, C.; Hartmann, K.; Hartmann, E.; Blome, C. Sustainable global supplier management: The role of dynamic capabilities in achieving competitive advantage. J. Supply Chain Manag. 2010, 46, 45-63. [CrossRef]

9. Ricketts, D.K.; Turvey, G.C.; Gómez, I.M. Value chain approaches to development: Smallholder farmer perceptions of risk and benefits across three cocoa chains in Ghana. J. Agribus. Dev. Emerg. Econ. 2014, 4, 2-22. [CrossRef]

10. Goodyear, D. The Future of Chocolate: Why Cocoa Production is at Risk; The Guardian: London, UK, 2013. Available online: http:/ / www.theguardian.com/sustainable-business/fairtrade-partner-zone/chocolate-cocoa-production-risk (accessed on 1 November 2014).

11. Fountain, A.; Huetz-Adams, F. Cocoa Barometer 2018; Public Eye: Zürich, Switzerland, 2018. Available online: www. cocoabarometer.org (accessed on 8 February 2019).

12. Change.org. Stop Hershey's from Using Child Slaves to Harvest Cocoa; Change.org: San Francisco, CA, USA, 2016. Available online: https:/ / www.change.org/p/the-hershey-company-stop-hershey-s-from-using-child-slaves-to-harvest-cocoa (accessed on 8 July 2019).

13. Sylla, N. The Fair Trade Scandal: Marketing Poverty to Benefit the Rich; Pluto Press: London, UK, 2014.

14. Kolk, A. Towards a sustainable coffee market: Paradoxes faced by a multinational company. Corp. Soc. Responsib. Environ. Manag. 2012, 19, 79-89. [CrossRef]

15. Izquierdo, N.C.; Tuesta, D. Factors that matter for financial inclusion: Evidence from Peru. Aestimatio IEB Int. J. Financ. 2015, $1,10-31$.

16. Fesenberg, C. Cocoa Value Chain Development: Transforming Cocoa Farming into a Sustainable Business for Smallholder Farmers; Swiss Foundation for Technical Cooperation: Zurich, Switzerland, 2012.

17. Rodríguez Valencia, M. The Practice of Co-Production through Biocultural Design: A Case Study among the Bribri People of Costa Rica and Panama. Sustainability 2020, 12, 7120. [CrossRef]

18. Gabler, C.B.; Panagopoulos, N.; Vlachos, P.A.; Rapp, A. Developing an environmentally sustainable business plan: An international B2B case study. Corp. Soc. Responsib. Environ. Manag. 2017, 24, 261-272. [CrossRef]

19. Porter, M.E.; Kramer, M.R. The link between competitive advantage and corporate social responsibility. Harvard Bus. Rev. 2006, 84, 78-92.

20. Porter, M.E.; Kramer, M.R. How to Fix Capitalism. The Big Idea and unleash a new wave of growth. Harvard Bus. Rev. 2011, 89, 3-17.

21. Dembek, K.; Singh, P.; Bhakoo, V. Literature review of shared value: A theoretical concept or a management buzzword? J. Bus. Ethics 2016, 137, 231-267. [CrossRef]

22. Crane, A.; Palazzo, G.; Spence, L.J.; Matten, D. Contesting the Value of "Creating Shared Value". Calif. Manag. Rev. 2014, 56, 130-153. [CrossRef]

23. Corazza, L.; Scagnelli, S.D.; Mio, C. Simulacra and sustainability disclosure: Analysis of the interpretative models of creating shared value. Corp. Soc. Responsib. Environ. Manag. 2017, 24, 414-434. [CrossRef]

24. UNESCO. Biodiversidad. Organización de las Naciones Unidas para la Educación, la Ciencia y la Cultura. 2017. Available online: http:/ / www.unesco.org/new / es/office-in-montevideo/natural-sciences/ecological-sciences/mab-lac-themes/ biodiversidad/ (accessed on 21 July 2019).

25. PromPeru. Cacao in Peru: A Rising Star; PromPeru: Lima, Peru, 2008. Available online: http://www.peru.org.tw/web/data/file/ userfiles / files /Cacao\%20Peru\%20Promperu.pdf (accessed on 26 June 2019).

26. Gootenberg, P. Cocaine Histories and Diverging Drug War Politics in Bolivia, Colombia, and Peru. Contracorriente Una Rev. De Estud. Latinoam. 2017, 15, 1-35.

27. Bureau for International Narcotics and Law Enforcement Affairs. International Narcotics Control Strategy Report, Volume I; United States Department of State: Washington, DC, USA, 2018.

28. Josephs, L. A sour bean sweetens cocoa supply. Wall St J. 19 March 2014. Available online: https://www.wsj.com/articles/noheadline-available-1395255922 (accessed on 20 May 2014).

29. Higuchi, A.; Coq-Hueva, D.; Arias-Gutierrez, R.; Alfalla-Luque, R. Farmer satisfaction and cocoa cooperative performance: Evidence from Tocache, Peru. Int. Food Agribus. Manag. Rev. 2020, 23, 217-234. [CrossRef]

30. Vanek-Smith, S. Ecuador's Answer to the Global Cocoa Shortage; NPR: Washington, DC, USA, 2015. Available online: https: //www.npr.org/2015/02/19/387420709/ecuadors-answer-to-the-global-cocoa-shortage (accessed on 14 June 2020).

31. UNODC. Desempeño Comercial de las Empresas Promovidas Por el Desarrollo Alternative; UNDOC: Vienna, Austria, 2012. Available online: http:/ / www.unodc.org/documents/peruandecuador/ / Publicaciones/Publicaciones2013/Libro_Final.pdf (accessed on 23 September 2014).

32. Michelini, L.; Fiorentino, D. New business models for creating shared value. Soc. Responsib. J. 2012, 8, 561-577. [CrossRef]

33. Kramer, M.R.; Pfitzer, M.W. The ecosystem of shared value. Harv. Bus. Rev. 2016, 94, 80-89.

34. Barzola Iza, C.L.; Dentoni, D.; Omta, O.S.W.F. The influence of multi-stakeholder platforms on farmers' innovation and rural development in emerging economies: A systematic literature review. J. Agribus. Dev. Emerg. Econ. 2020, 10, 13-39. [CrossRef]

35. Czinkota, M.R.; Boeckmann, K. The honorable merchant in international marketing: An ancient concept newly needed. Thunderbird Int. Bus. Rev. 2016, 58, 185-188. [CrossRef]

36. Abu El-Ella, N.; Bessant, J.; Pinkwart, A. Revisiting the honorable merchant: The reshaped role of trust in open innovation. Thunderbird Int. Bus. Rev. 2016, 58, 261-275. [CrossRef] 
37. Creswell, J.W. Research Design: Qualitative, Quantitative and Mixed Methods, 4th ed.; Sage Publications: Thousand Oaks, CA, USA, 2014.

38. Høgevold, N.M.; Svensson, G. A business sustainability model: A European case study. J. Bus. Ind. Mark. 2012, 27, 142-151. [CrossRef]

39. Jurietti, E.; Mandelli, A.; Fudurić, M. How do virtual corporate social responsibility dialogs generate value? A case study of The Unilever Sustainable Living Lab. Corp. Soc. Responsib. Environ. Manag. 2017, 24, 357-367. [CrossRef]

40. Yin, R.K. Case Study Research: Design and Method, 4th ed.; Sage Publications: Thousand Oaks, CA, USA, 2009.

41. Morales, O.; Borda, A.; Argandoña, A.; Farach, R.; Garcia Naranjo, L.; Lazo, K. La Alianza Cacao Perú y la Cadena Productiva del Cacao Fino de Aroma; Universidad ESAN Ediciones: Lima, Peru, 2015.

42. Cook, K.E. In-depth interview. In The Sage Encyclopaedia of Qualitative Research Methods; Given, L.M., Ed.; Sage Publications: Thousand Oaks, CA, USA, 2008; Volumes 1 \& 2, pp. 242-243.

43. Palys, T. Purposive sampling. In The Sage Encyclopaedia of Qualitative Research Methods; Given, L.M., Ed.; Sage Publications: Thousand Oaks, CA, USA, 2008; Volumes 1 \& 2, pp. 696-697.

44. Maxwell, J.A. Designing a qualitative study. In The SAGE Handbook of Applied Social Research Methods, 2nd ed.; Sage Publications: Thousand Oaks, CA, USA, 2009; pp. 214-253.

45. Julien, H. Content analysis. In The Sage Encyclopaedia of Qualitative Research Methods; Given, L.M., Ed.; Sage Publications: Thousand Oaks, CA, USA, 2008; Volumes 1 \& 2, pp. 120-122.

46. Porter, M.E.; Hills, G.; Pfizer, M.; Patscheke, S.; Hawkins, E. Measuring Shared Value How to Unlock Value by Linking Social and Business Results; FSG: Boston, MA, USA, 2011. Available online: https://www.hbs.edu/ris/Publication\%20Files/Measuring Shared_Value_57032487-9e5c-46a1-9bd8-90bd7f1f9cef.pdf (accessed on 14 July 2021).

47. ICCO. Fine or Flavour Cocoa; ICCO: Abidjan, Côte d'Ivoire, 2019. Available online: https:/ /www.icco.org/about-cocoa/fine-orflavour-cocoa.html (accessed on 26 June 2019).

48. CAF. Fine Cocoa, Latin America's Jewel; CAF: Caracas, Venezuela, 2017. Available online: https://www.caf.com/en/currently/ news / 2017/04/ fine-cocoa-latin-americas-jewel/ (accessed on 26 June 2019).

49. Nieburg, O. CCN-51: Cocoa's Shining Light or a Risky Monocrop? Confectionery News. 8 August 2016. Available online: https: / / www.confectionerynews.com/Article/2016/08/09/CCN-51-Cocoa-s-shining-light-or-a-risky-monocrop (accessed on 26 June 2019).

50. Peru Cocoa Alliance. Peru Cocoa Alliance Final Report: An Inclusive Market Systems Approach to Alternative Development; Peru Cocoa Alliance: Lima, Peru, 2019. Available online: https:/ / camcafeperu.com.pe/admin/recursos/publicaciones/Informe-finalAlianza-Peruana-del-Cocoa.pdf (accessed on 26 June 2019).

51. Illge, L.; Preuss, L. Strategies for sustainable cotton: Comparing niche with mainstream markets. Corp. Soc. Responsib. Environ. Manag. 2012, 19, 102-113. [CrossRef] 